\title{
Phytochemical Screening and Antioxidant Activities of the Seedling Extracts from Inca Peanut Plukenetia volubilis
}

\author{
Darunee Puangpronpitag ${ }^{1}$, Puangpaka Tankitjanon ${ }^{2}$, Adisak Sumalee ${ }^{2}$, Ampa Konsue ${ }^{3, *}$
}

Darunee Puangpronpitag', Puangpaka Tankitjanon ${ }^{2}$, Adisak Sumalee ${ }^{2}$, Ampa Konsue ${ }^{3, *}$

'Biomedical Research Unit, Faculty of Medicine, Mahasarakham University, THAILAND.

${ }^{2}$ Sukhothai Thammatirat Open University, Nonthaburi, 11120, THAILAND.

${ }^{3}$ Thai Traditional Medicinal Research Unit, Applied Thai Traditional Medical Program, Faculty of Medicine, Mahasarakham University, Maha Sarakham, 44000, THAILAND.

\section{Correspondence}

\section{Ampa Konsue}

Thai Traditional Medicinal Research Unit, Applied Thai Traditional Medical Program,

Faculty of Medicine, Mahasarakham University, Maha Sarakham, 44000, THAILAND.

E-mail: ampa_ice@hotmail.com

\section{History}

- Submission Date: 21-09-2020;

- Review completed: 28-10-2020;

- Accepted Date: 21-11-2020.

DOI : 10.5530/pj.2021.13.8

Article Available online

http://www.phcogj.com/v13/i1

\section{Copyright}

(c) 2021 Phcogi.Com. This is an openaccess article distributed under the terms of the Creative Commons Attribution 4.0 International license.

\begin{abstract}
Background: Plukenetia volubilis L., Inca peanut is an oleaginous plant, widely cultivated as commercially in South East Asia, especially in Thailand. The oil from the seed plant is a greatest interesting a natural source. Objectives: The aims of this study were investigated phytochemical screening, to evaluated the total flavonoids and phenolic compound contents as well as antioxidant activities of seedling extract from $P$. volubilis. Methods: The dried $P$. volubilis seedlings of 21 days growing period were extracted by using different solvent including aqueous (ASS), 50\% ethanolic (HESS), and 95\% ethanolic (ESS) extracts. The phytochemical screenings were determined on total phenolic compound (TPC) and flavonoid (TFC) contents. The antioxidation were tested by using 2,2-diphenyl-1-picrylhydrazy radical scavenging (DPPH), 2,2 -azinobis-(3-ethylbenzothiazoline-6-sulphonate) (ABTS+) assay, and ferric reducing antioxidant power (FRAP). Results: The results found that the ESS were significantly highest amount on total phenolic compound $(23.0809 \pm 0.8632 \mathrm{mgGE} / \mathrm{gExt})$ and flavonoid $(466.3839 \pm 1.5580$ $\mathrm{mgQE} / \mathrm{gExt})$ contents. In this study, ascorbic acid ( $\left.\mathrm{IC}_{50}=0.016 \pm 0.0003 \mathrm{mg} / \mathrm{mL}\right)$ and Trolox $\left(I C_{50}=0.044 \pm 0.0008 \mathrm{mg} / \mathrm{mL}\right)$ as standard substances were showed more potent than all of the extracts from $P$. volubilis seedlings. Surprisingly, the ESS has more potent on free radical scavenging higher than different solvents; $\mathrm{DPPH}=0.007 \pm 0.001\left(I \mathrm{C}_{50}=\mathrm{mg} / \mathrm{mL}\right), A B T S=1.4065 \pm$ $0.0505\left(I C_{50}=\mathrm{mg} / \mathrm{mL}\right)$, and FRAP $=74.4960 \pm 2.6067$ (mg=TE/gExt). Conclusion: the plant seedling extracts composed with high amount of flavonoids and phenolic compound contents possess valuable to antioxidant activities. The seedling extracts from the plant could apply to supplementary food, cosmetic, pharmaceutical, and horticultural industries. Next study, chemical compositions, the major active compound(s), and biological activities will be clarified. Key Words: Phytochemical screening, Flavonoids, Phenolic compounds, Plukenetia volubilis, Inca peanut seedling, Antioxidant activity.
\end{abstract}

\section{INTRODUCTION}

The secondary metabolites, flavonoids, phenolic compounds present in different parts of the plants provide protection against also the pathogens and protect the plants from UV radiations ${ }^{1}$. Flavonoid(s) is a phenolic compound derivative, component in nature and distributed in many parts of plant ${ }^{2}$. The molecular structure is process to stop oxidation of cells within human body ${ }^{3}$. The phenolic compounds in plant against chronic conditions including cardiovascular diseases, neurodegeneration, and certain kinds of cancer ${ }^{4}$. The oxidative stress results from an improper balance between Reactive Oxygen Species (ROS) and their metabolites and antioxidant defense cause some factor in the pathogenesis of various diseases $^{5}$. The reaction of free radical such as hydrogen peroxide and superoxide radical yields the hydroxyl radical $(\cdot \mathrm{OH})$ which is highly reactive and damaging to most biomolecules ${ }^{6}$. Antioxidant mechanisms, electron donated, hydrogen atom transfer (HAT), single electron transfer (SET), and the ability to chelate transition metals. The importance of antioxidant mechanisms is to understand the biological meaning of antioxidants, their possible uses, their production by organic synthesis or biotechnological methods, or for the standardization of the determination of antioxidant activity $^{7}$

Plukenetia volubilis $\mathrm{L}$., is a climbing shrub plant commonly known as sacha peanut, mountain peanut or inca peanut, a perennial plant with somewhat hairy leaves, belonging to the Euphorbiaceae family. It is widely also being cultivated commercially in South East Asia, especially in Thailand ${ }^{8-9}$. The seed obtained with mainly oil, which is characterized by having a high unsaturated fatty acid content including oleic, linoleic, and linolenic acid. The oil extraction process generates a sub-product with high protein contents ${ }^{10}$. Inca peanut seeds contained the largest amount of protein $(62.07 \%)$ and carbohydrates $(82.68 \%)$. Moreover, it also contains with essential amino acid such as Lysine, leucine, histidine, and phenylalanine ${ }^{11}$. The seeds were contained $25-27 \%$ protein and $41-54 \%$ of oil which comprises approximately $90 \%$ unsaturated fatty acids (oleic, linoleic, and linolenic acid) and is rich in vitamins $\mathrm{E}$ (alpha-tocopherols) and A (carotenoids) ${ }^{12-14}$. Phytochemical constituents from seed of the plant composed of fatty acids, phytosterols, tocopherols, phenolic compounds, total carotenoids, and hydrophilic and lipophilic capacities $^{15}$. Several secondary metabolites such as phenolics, flavonoids, alkaloids derived from plants show superfluous antioxidant potential. The

Cite this article: Puangpronpitag D, Tankitjanon $P$, Sumalee A, Konsue A. Phytochemical Screening and Antioxidant Activities of the Seedling Extracts from Inca Peanut Plukenetia volubilis. Pharmacog J. 2021;13(1): 52-8. 
unsaturated fatty acid such as omega- 3 are very important to the nutraceutical industrial because associated with a number of health benefits, such as prevent fatal cardiovascular disease, coronary heart disease prevention, diabetes prevention, hypertension prevention, and others ${ }^{16}$. Inca peanut grain is an excellent source of bioactive molecules such as phytosterols which decrease the risk of certain types of cancer, reduce cholesterol in the blood, prevent cardiovascular diseases, decrease the risk of heart and other chronic diseases, increase HDL (high density lipoprotein) blood quantities, prevent cancer and relief the effects of auto-immune diseases, rheumatoid arthritis, and depression ${ }^{17}$. The oil from the plant is a greatest interesting a natural source with potential to applications in the food, cosmetic, and pharmaceutical industries ${ }^{18-19}$.

Although, P. volubilis were widely used for supplementary food, cosmetic, and pharmaceutical industries. There are so many literatures that have been reported to the effect of the seed from $P$. volubilis but still not yet any article of plant seedling. The purposes of this study were investigated phytochemical screening and antioxidant activities of seedling extract from the plant.

\section{MATERIALS AND METHODS}

\section{Sample collection}

P. volubilis seeds were acquired from Loei Province, Northeastern of Thailand. The specimens were identified and deposited at the Faculty of Medicine, Mahasarakham University, Thailand (code; $P$. volubilis: MSU. MED- PV0001/ AK). The white P. volubilis seedlings were cultivated at the experimental farm of Faculty of Medicine, Mahasarakham University, Maha Sarakham, Thailand. The seeds eliminated when they were deformed. The seed soaking at room temperature for $12 \mathrm{hr}$ at before sowing in seed sponge with $2.54 \times 2.54 \times 2.54 \mathrm{~cm}$. given to distilled water daily during 21 days. After day $21^{\text {st }}$, the fresh seedlings were cleaned and dried at $50^{\circ} \mathrm{C}$ for $48 \mathrm{hr}$ in a hot air oven, then powdered.

\section{Preparation of extracts}

The aqueous extract (ASS) was prepared by boiling with distilled water for $15 \mathrm{~min}(1: 10 \mathrm{w} / \mathrm{v})$. The boiling process was repeated twice. The hydroethanolic extracts (HESS) and ethanolic extracts (ESS) were macerated with $50 \%$ ethanol and 95\% ethanol for 7 days $(1: 5 \mathrm{w} / \mathrm{v})$. The residue powder was excluded by using filter papers (Whatman, Germany). The filtrate was evaporated using by a rotary evaporator (Heidolph Laborota 4000 , Germany) and then freeze-dried to obtain dark brown extract. The extracts were kept in the refrigerator at temperature below $4{ }^{\circ} \mathrm{C}$ until be used.

\section{DETERMINATION OF PHYTOCHEMICAL SCREENING}

\section{Total flavonoid content assay}

Flavonoid content was estimated using the aluminum chloride colorimetric method ${ }^{[20}$. The extracts from recipe will be mixed with 100 $\mu \mathrm{L}$ of $5 \%$ aluminum chloride (w/v), $400 \mu \mathrm{L}$ of $2.5 \% \mathrm{Na}_{2} \mathrm{NO}_{3}$ After 5 min, $500 \mu \mathrm{L}$ of $5 \% \mathrm{AlCl}_{3}$. The mixture will be allowed to stand at room temperature for $10 \mathrm{~min}$. The solution was mixed 2,000 $\mu \mathrm{L}$ distilled water. The results were measured at $415 \mathrm{~nm}$. The TFC was calculated from a standard Quercetin equivalent (mgQE/gExt).

\section{Total phenolic compound content assay}

Total phenolic compound content was determined according to a modified procedure ${ }^{21}$. Sample $(100 \mu \mathrm{L})$ will be oxidized with $500 \mu \mathrm{L}$ of $0.2 \mathrm{~N}$ Folin-Ciocalteu's reagent and neutralized by adding $400 \mu \mathrm{L}$ of $7.5 \% \mathrm{Na}_{2} \mathrm{CO}_{3}$. The absorbance measured at $765 \mathrm{~nm}$ after mixed will be allowed to stand at room temperature for $30 \mathrm{~min}$. The results were expressed as gallic acid equivalents (mgGE/gExt).

\section{DETERMINATION OF ANTIOXIDANT ACTIVITIES}

\section{DPPH free radical scavenging assay}

2,2-Diphenyl-2-picrylhydrazyl (DPPH) radical scavenging capacities of wheat extracts were estimated by the reduction of the reaction color between DPPH solution and sample extracts as previously described by prior method $^{22}$. DPPH was dissolved in ethanol to a $0.039 \mathrm{mg} / \mathrm{mL}$. The plant extract at various concentrations was diluted with distilled water to get sample solution. Then, $100 \mu \mathrm{L}$ of the sample solution following which $900 \mu \mathrm{L} \mathrm{DPPH}(0.1 \mathrm{mM})$ working solution. After a 30 min reaction kept in the dark at ambient temperature then absorbance of the solution was measured at $515 \mathrm{~nm}$. In this study, will be used Trolox $^{\circledR}$ and ascorbic acid as standard substances. Blanks were run in each assay. DPPH radical ability was expressed as $\mathrm{IC}_{50}(\mathrm{mg} / \mathrm{mL})$ and the inhibition percentage calculated using the following formula: DPPH scavenging activity $(\%)=\left(\mathrm{A}_{0}-\mathrm{A}_{1}\right) / \mathrm{A}_{0} \times 100$ where $\mathrm{A}_{0}$ is the absorbance of the control and $A_{1}$ is the absorbance of the sample.

\section{$\mathrm{ABTS}^{+}$radical scavenging assay}

In ABTS assay, the plants extract will be allowed to react with $\mathrm{ABTS}^{+}$, a model stable free radical derived from 2,2-azinobis (3-ethylvenzothiazolin-6-sulphonic acid) $\left(\mathrm{ABTS}^{+}\right)$assay was performed ${ }^{23}$. The $\mathrm{ABTS}^{+}(900 \mu \mathrm{L})$ was added to the extracts $(100 \mu \mathrm{L})$ and thoroughly mixed. The mixture was held at room temperature for $6 \mathrm{~min}$, and absorbance was immediately measured at $734 \mathrm{~nm}$. Trolox ${ }^{\circledR}$ and ascorbic acid solution in $80 \%$ ethanol was prepared and assayed under the same conditions. ABTS scavenging ability was expressed as $\mathrm{IC}_{50}(\mathrm{mg} / \mathrm{mL})$ and the inhibition percentage calculated using the following formula: ABTS scavenging activity $(\%)=\left(A_{0}-A_{1}\right) / A_{0} \times 100$ where $A_{0}$ is the absorbance of the control and $A_{1}$ is the absorbance of the sample.

\section{Ferric reducing antioxidant power (FRAP) assay}

The ferric reducing ability of the extract will be measured at low $\mathrm{pH}^{24-25}$. Sample $(100 \mu \mathrm{L})$ will be oxidized with FRAP reagent $900 \mu \mathrm{l}(300 \mathrm{mM}$ Acetate buffer ( $\mathrm{pH}$ 3.6): $10 \mathrm{mM}$ tripyridyl triazine (tptz) solution: 20 $\mathrm{mM}$ Ferric chloride solution of 10: 1: 1). This will be incubated for 5 min at $37^{\circ} \mathrm{C}$. An intense blue coloured complex will be formed when $\mathrm{Fe}^{3+}$-TPTZ complex could be reduced to the ferrous $\left(\mathrm{Fe}^{3+}\right)$ form. The absorbance at $593 \mathrm{~nm}$ will be recorded. The reducing power of the samples increased with the absorbance values. The results were expressed as Trolox ${ }^{\circledR}$ equivalent (mgTE/gExt).

\section{Statistical analysis}

All data were expressed as mean \pm standard error of mean (SEM) from four separate experiments $(n=4)$. Total variation of data carried out using one-way analysis of variance (ANOVA). Differences between means were determined using Duncan's multiple range tests. Differences at $p<0.05$ considered significantly.

\section{RESULTS}

\section{Total phenolic compound content}

Total phenolic compound content showed that 95\% ethanolic extract had TPC higher than different extracts. The TPC found that ESS (23.0809 $\pm 0.8632 \mathrm{mgGE} / \mathrm{gExt})$ was higher than hydro-ethanolic and aqueous extracts $(1.7144 \pm 0.0346,1.5319 \pm 0.0286 \mathrm{mgGE} / \mathrm{gExt})$ respectively (Table 1). 


\section{Total flavonoid content}

Total flavonoid content showed that 95\% ethanolic extract had TFC higher than different extracts. The TFC found that ESS $(466.3839 \pm 1.5580$ $\mathrm{mgQE} / \mathrm{gExt}$ ) was higher than hydro-ethanolic and aqueous extracts $(310.1624 \pm 16.6718$ and $284.8477 \pm 7.8958 \mathrm{mgQE} / \mathrm{gExt})$ respectively (Table 1).

\section{Antioxidant activities}

\section{DPPH free radical scavenging activity}

In this study, standard substances, ascorbic acid $\left(\mathrm{IC}_{50}=0.016 \pm 0.0003\right.$ $\mathrm{mg} / \mathrm{mL})$ and Trolox $^{\circledR}\left(\mathrm{IC}_{50}=0.044 \pm 0.0008 \mathrm{mg} / \mathrm{mL}\right)$ were showed more potent than all of the extract from Inca peanut seedlings. The ESS ( $\mathrm{IC}_{50}$ $=0.007 \pm 0.001 \mathrm{mg} / \mathrm{mL}$ ) was exerted on anti-oxidation higher than HESS and ASS $\left(\mathrm{IC}_{50}=4.4675 \pm 0.2450\right.$ and $\left.4.9150 \pm 0.2669 \mathrm{mg} / \mathrm{mL}\right)$ respectively (Table 2).

\section{$\mathrm{ABTS}^{+}$radical scavenging activity}

The $\mathrm{ABTS}^{+}$assay, the standard substances, ascorbic acid $\left(\mathrm{IC}_{50}=0.0250\right.$ $\pm 0.0010 \mathrm{mg} / \mathrm{mL}$ ) and Trolox $\left(\mathrm{IC}_{50}=0.0320 \pm 0.0010 \mathrm{mg} / \mathrm{mL}\right.$ ) were still showed more potent than all of the various solvent extracts from Inca peanut seedlings. The ESS $\left(\mathrm{IC}_{50}=1.4065 \pm 0.0505 \mathrm{mg} / \mathrm{mL}\right)$ had been more potent than HESS and ASS $\left(\mathrm{IC}_{50}=1.5398 \pm 0.0305\right.$ and $1.7215 \pm 0.0756$ $\mathrm{mg} / \mathrm{mL}$ ) respectively (Table 2 ).

\section{Ferric reducing antioxidant power (FRAP) activity}

In this study, standard substances, ascorbic acid and Trolox were showed more potent than all the extract of Inca peanut seedlings The ESS (74.4960 $\pm 2.6067 \mathrm{mgTE} / \mathrm{gExt})$ was exerted on antioxidation higher than HESS and ASS $(34.6960 \pm 1.3396,28.0588 \pm 0.7758 \mathrm{mgTE} / \mathrm{gExt})$ respectively (Table 2 ).

\section{DISCUSSION}

Currently, P.volubilis, Sacha inchi, or Inca peanut has been cultivated into sustainable agricultural systems provides new developmental opportunities and can increase the resilience of food production systems. It has a high potential for replacing illicit crops and the establishment of commercial plantations generate positive environmental impacts because it could be install on degraded soils ${ }^{26}$. Its grows on the tropical humid monsoon regions where annual rainfall is high and the wettingdrying cycles resulted in temporal changes in soil structure ${ }^{27}$. The parameter of seedling germination was approximately stimulated by vermiculite, continuous light, and $30^{\circ} \mathrm{C}$ temperature ${ }^{28}$.

The oil has a higher omega-3 (40\%-50\%) and omega-6 (30\%-40\%) contents and a lower oleic acid (10\%) content than olive oil. The omega- 6 fatty acid linoleic acid plays a role in the regeneration of the lipid barrier structure in the seed plant. Natural antioxidants, including tocopherols and polyphenol have been found in the oil. The present study, the seedling extracts showed stronger on free radical scavenging which the extract composition with the tocopherols, known as vitamin $\mathrm{E}$ is an important minor component in oil that may be antioxidative and slow down the process of oxidation ${ }^{29}$. Moreover, phenolic compounds, flavonoids were detected in seedling extracts that are good for the oil's oxidative stability of polyunsaturated fatty acids imparting the characteristic flavor to the oil. So many polyphenols have beneficial effects on various diseases including hypertension and atherosclerosis, play roles in the prevention of certain cancers and modification of immune responses. The high content of tocopherols could play a major antioxidant role in the oil, or in synergy with phenolic compounds, which might be also adding more nutritional value as antioxidants and are probably the main components responsible for oxidative stability ${ }^{30}$.

The reviewed literature, some cereals such as Inca peanut were recommended compositions with phenolic substance and $\alpha$-Tocopherol presence high antioxidant activity, most investigators are using a combination of antioxidant tests. Many investigators showed the importance of the use of antioxidant assays in assessment of bioactivity of natural products, which related mainly to the bioactivity of their phenolic compounds. It was shown that these natural products are active in prevention and treatment of various diseases including heart diseases and even of cancer ${ }^{31}$. While several species of Plukenetia have ornamental value, the genus is best known for the health promoting properties of $P$. volubilis, it is the consumption of $\Omega-3$ and -6 fatty acids have been shown to prevent cardiovascular diseases, heart diseases, and cancer, and can have a hypocholesterolemic effect ${ }^{31-32}$.

Recently issues, Non-communicated diseases (NCD) such as cancer, diabetes, arteriosclerosis, inflammatory disease, autoimmunity, cardiovascular disease, and Alzheimer's have been associated with the increase of reactive oxygen species (ROS) or the inability of the organism to reduce these ROS that was normally produced by the organism cells, a process known as oxidative stress. Antioxidants are important substances, which have the ability to protect the organism from the damage caused by oxidative stress. Due to this ability,

Table 1: Phytochemical screening methods including total phenolic (TPC) and flavonoid (TFC) contents of various solvent extracts from Inca peanut seedlings.

\begin{tabular}{ccc}
\hline & $\begin{array}{c}\text { TPC } \\
(\mathrm{mgGE} / \mathrm{gExt})\end{array}$ & $\begin{array}{c}\text { TFC } \\
\text { (mgQE/gExt) }\end{array}$ \\
\hline Aqueos extract & $1.5319 \pm 0.0286 \mathrm{a}$ & $284.8477 \pm 7.8958 \mathrm{a}$ \\
Hydro-ethanolic extract & $1.7144 \pm 0.0346 \mathrm{~b}$ & $310.1624 \pm 16.671 \mathrm{~b}$ \\
Ethanolic extract & $23.0809 \pm 0.8632 \mathrm{c}$ & $466.3839 \pm 1.5580 \mathrm{c}$ \\
\hline
\end{tabular}

TPC was measured with gallic acid equivalents (mgGE/gExt). TFC was measured with quercetin equivalent (mgQE/gExt). Different letters indicated significantly difference at $p$-values less than 0.05 .

Table 2: Antioxidant activities showed $\mathrm{IC}_{50}$ of various solvent extracts from Inca peanut seedlings.

\begin{tabular}{cccc} 
& $\begin{array}{c}\text { DPPH } \\
\left(\mathrm{IC}_{50}=\mathrm{mg} / \mathrm{mL}\right)\end{array}$ & $\begin{array}{c}\text { ABTS } \\
\left(\mathrm{IC}_{50}=\mathrm{mg} / \mathrm{mL}\right)\end{array}$ & $\begin{array}{c}\text { FRAP } \\
\text { (mg=TE/gExt) }\end{array}$ \\
\hline Aqueos extract & $4.9150 \pm 0.2669 \mathrm{~d}$ & $1.7215 \pm 0.0756 \mathrm{~d}$ & $28.0588 \pm 0.7758 \mathrm{a}$ \\
Hydro-ethanolic extract & $4.4675 \pm 0.2450 \mathrm{c}$ & $1.5398 \pm 0.0305 \mathrm{c}$ & $34.6960 \pm 1.3396 \mathrm{~b}$ \\
Ethanolic extract & $0.007 \pm 0.001 \mathrm{~b}$ & $1.4065 \pm 0.0505 \mathrm{~b}$ & $74.4960 \pm 2.6067 \mathrm{c}$ \\
Ascorbic acid & $0.016 \pm 0.0003 \mathrm{a}$ & $0.0250 \pm 0.0010 \mathrm{a}$ & - \\
Trolox $^{\circledR}$ & $0.044 \pm 0.0008 \mathrm{a}$ & $0.0320 \pm 0.0010 \mathrm{a}$ & - \\
\hline
\end{tabular}

DPPH radical scavenging, $\mathrm{ABTS}^{+}$and FRAP assay were used Trolox ${ }^{\circledR}$ and ascorbic acid as standard substances. Different letters indicated significantly difference at $p$-values less than 0.05 . 
there is a special interest in the presence of natural antioxidants in medicinal plant that may help an organism to keep the normal balance of $\operatorname{ROS}^{33}$. Antioxidants could be use for the management of some pathophysiological conditions, which involve free radicals. Flavonoid and phenolic compounds may be useful as antioxidants from natural sources. The distribution of phenolic compounds varies between different parts of the plant $^{34}$. Inca peanut seedlings enhanced the capacity of antioxidants, which increased the capacity of antioxidant enzymes and decreased the level of $\operatorname{ROS}^{35}$. Our data found that the Inca peanut seedling composed of flavonoids and phenolic compounds and antioxidant activities, it is might be prevented and improve some systemic diseases. The seedling extracts presence of flavonoids and phenolic compounds have shown that the antioxidant activities may be relate to compound ingredients that cloud be prevented the biological and chemical substances from radical induced oxidation damage. Because radical oxidation of substrates occurs through a chain reaction involving three stages (i.e., initiation, propagation, and termination), antioxidants show their effects through various mechanisms ${ }^{36}$.

In any way, the seedling consumption, Heat processing should be apply before consumption Inca peanut in order to reduce phytotoxins and potential health risks. Roasting could be most effectively reducing these phytotoxins, and hence, thermal processing should be applied before the consumption of Inca peanut ${ }^{31,37}$. The approximately heating inducing on Inca peanut seeds (at $160^{\circ} \mathrm{C}$ for 15 mins) might be increased total phenolic compound contents and improved antioxidant inhibitory activity has been reported for the plant seed ${ }^{38}$. The results obtained in this study indicated that the seedling is an important source of antioxidant from phenolic compounds. It contained with condensed tannins (93.1\%), the main family of phenolic compounds present in plants. The other phenolic families in seeds (hydrolyzed tannin, free and bound phenolic acids, flavanoids, flavonoids, and lignans) were present in amounts. Thus, our results indicated that the seedling has a high potential as an alternative and novel source of antioxidant phenolic compounds from an agro-industry by product that could be derive to the functional food industry ${ }^{39}$. It is of growing economic importance in the supplementary food, pharmaceutical, cosmetic, and horticultural industries ${ }^{[40}$.

In our finding, the phytochemical screening were detected flavonoids and phenolic compound contents of plant seedling extracts which their composition has more potent on antioxidant activity (DPPH, ABTS, and FRAP) properties. Thus, should be additional study on germination, survival, cultivation, and harvesting practice to obtained major or/and active components in the seedling.

\section{CONCLUSION}

In conclusion, the $P$. volubilis seedling extracts were carried out to evaluated phytochemical screening also the flavonoids and phenolic compound contents and the antioxidant activities (DPPH, ABTS, and FRAP) ability. The results demonstrated that the seedling extracts composed with high amount of flavonoid and phenolic compound contents possess valuable to antioxidant activities. The seedling extracts from the plant could be apply to supplementary food, cosmetic, pharmaceutical, and horticultural industries. Future study, chemical compositions, the major active compound(s), and biological activities will be clarified.

\section{ACKNOWLEDGEMENT}

The authors sincerely thank Faculty of Medicine, Mahasarakham University, Maha Sarakham, Thailand for financial supported.

\section{FINANCIAL SUPPORT AND SPONSORSHIP}

The study was partially financially supported by Faculty of Medicine, Mahasarakham University, Maha Sarakham, Thailand.

\section{CONFLICTS OF INTEREST}

The authors have no conflict of interest to declare and are responsible for the content and writing of the manuscript.

\section{ABBREVIATIONS}

ASS: Aqueous extract; HESS: 50\% Ethanolic extract; ESS: $95 \%$ Ethanolic extract; ABTS: 2,2'-azino-bis(3-ethylbenzothiazoline-6sulphonic acid); DPPH: 2,2-diphenyl-1-picrylhydrazyl; FRAP: Ferric reducing antioxidant power; mgGE/gExt: Gallic acid equivalent; mgQE/gExt: Quercetin equivalent; TE/gExt: Trolox ${ }^{\circledR}$ equivalent; Trolox ${ }^{\circledR}$ : 2-carboxy-2,5,7,8-tetramethyl-6-chromanol; TFC: Total flavonoid content; TPC: Total phenolic compound content.

\section{REFERENCES}

1. Kothari-Chhajer A, Samad A, Reema, Vasu Kirtana, Karan J, Dhiman AC, et al. Comparative analysis of antioxidant activity in various plant species. DU J Undergrad Res Inn. 2016;2(1):7-12.

2. Gu Q, Duan G, Yu X. Bioconversion of flavonoid glycosides from Hippophae rhamnoides leaves into flavonoid aglycones by Eurotium amstelodami. Microorganisms. 2019; 7: 122.

3. Raza Hassan, Shehzad MA, Baloach A, Ikram RM. Antioxidant and antimicrobial activity of fruit juices. Int J Agri Sus Dev. 2019;1(3):94-102.

4. Mena P, Ludwig IA, Tomatis VB, Acharjee A, Calani L, Rosi $A$, et al. Inter individual variability in the production of flavan-3-ol colonic metabolites: preliminary elucidation of urinary metabotypes. Euro J Nut. 2018.

5. Chanhan P, Konsue A, Nammatra R. Effect of agricultural model of using fertilizer, harvesting time and extraction method on phytochemical contents and antioxidant activities from mulberry leaves grown in Maha Sarakham Province, Thailand. Pharmacog J. 2019;11(3):531-5

6. Stone WL, Basit H, Mohiuddin SS. Biochemistry, Antioxidants. NCBI Bookshelf. A service of the National Library of Medicine, National Institutes of Health 2019.

7. Santos-Snchez NF, Salas-Coronado R, Villanueva-Caongo C, Hernndez-Carlos B Antioxidant compounds and their antioxidant mechanism.

8. Saengsorn K, Jimtaisong A. Determination of hydrophilic-lipophilic balance value and emulsion properties of sacha inchi oil. Asian Pac J Trop Biomed. 2017;7(12):1092-6.

9. Flores S, Flores A, Calderon C, Obregon D. Synthesis and characterization of sacha inchi (Plukenetia volubilis L.) oilbased alkyd resin. Prog Org Coat. 2019;136:105289.

10. Micanquer-Carlosama A, Cortes-Rodríguez M, Serna-Cock L. Formulation of a fermentation substrate from pineapple and sacha inchi wastes to grow Weissella cibaria. Heliyon. 2020;6:e03790.

11. Rawdkuen $S$, Murdayanti $D$, Ketnawa $S$, Phongthai $S$. Chemical properties and nutritional factors of pressed-cake from tea and sacha inchi seeds. Food Biosci. 2016;15:64-71.

12. Fu Q, Niu L, Chen MS, Tao YB, Wang X, He H, Pan BZ, et al. De novo transcriptome assembly and comparative analysis between male and benzyladenine-induced female inflorescence buds of Plukenetia volubilis. J Plant Physiol. 2018;221:107-18.

13. Vicente J, de Carvalho MG, Garcia-Rojas EE. Fatty acids profile of Sacha Inchi oil and blends by 1H NMR and GC-FID. Food Chem. 2015.

14. Hadzich A, Gross GA, Leimbach M, Ispas A, Bund A, Flores S. Characterization of Plukenetia volubilis L. fatty acid-based alkyd resins. Polym Test. 2020.

15. Chirinos R, Zuloeta G, Pedreschi R, Mignolet E, Larondelle Y, Campos D. Sacha inchi (Plukenetia volubilis): A seed source of polyunsaturated fatty acids, tocopherols, phytosterols, phenolic compounds and antioxidant capacity. Food Chem. 2013;141:1732-9.

16. Da Silva Soares B, Siqueira RP, de Carvalho MG, Vicentea J, Garcia-Rojas EE. Microencapsulation of sacha inchi oil (Plukenetia volubilis L.) using complex coacervation: Formation and structural characterization. Food Chem. 2019:298:125045.

17. Zanqui $A B$, da Silva $C M$, de Morais DR, Santos JM, Ribeiro SAO, Eberlin MN, et al. Sacha inchi (Plukenetia volubilis L.) oil composition varies with changes in temperature and pressure in subcritical extraction within-propane. Ind Crop Prod. 2016;87:64-70

18. Hadzich A, Gross GA, Leimbach M, Ispas A, Bund A, Flores S. Characterization of Plukenetia volubilis L. fatty acid-based alkyd resins. Polym Test. 2020.

19. Sanchez-Reinoso Z, Mora-Adames WI, Fuenmayor CA, Darghan-Contreras AE, Gardana C, Gutiérrez LF. Microwave-assisted extraction of phenolic compounds from Sacha Inchi shell: Optimization, physicochemical properties and evaluation of their antioxidant activity. Chem Eng Process. 2020. 
20. Chang $\mathrm{C}$, Yang M, Wen $\mathrm{H}$, Chern J. Estimation of total flavonoid content in propolis by two complementary colorimetric methods. J Food Drug Anal. 2002;10:178-82.

21. Singleton VL, Orthofer R, Lamuela-Raventos RM. Analysis of total phenols and other oxidation substrates and antioxidants by means of Folin-Ciocalteu reagent. Meth Enzymol. 1999;299:152-78.

22. Ursini F, Mairorino M, Morazzoni P, Roveri A, Pifferi G. Anovel antioxidant flavonoid (IdB 1031) affecting molecular mechanisms of cellular activation. Free Rad Biol Med. 1994;16:547-53.

23. Long LH, Halliwell B. Oxidation and generation of hydrogen peroxide by thiol compounds in commonly used cell culture media. Biochem Biophys Res Commun. 2001;286:991-4.

24. Benzie IF, Strain JJ. The ferric reducing ability of plasma (FRAP) as a measure of "antioxidant power": The FRAP assay. Anal Biochem. 1996;239:70-6.

25. Rajurkar NS, Hande SM. Estimation of phytochemical content and antioxidant activity of some selected traditional indian medicinal plants. Indian J Pharm Sci. 2011;73(2):146-51.

26. Solis R, Gonzales N, Pezo M, Arévalo L, Vallejos-Torres G. Rooting of sacha inchi (Plukenetia volubilis) juvenile cuttings in microtunnels. Acta Agron. 2019;68(1):35-40

27. Gong HD, Geng YJ, Yang C, Jiao DY, Chen L, Cai ZQ. Yield and resource use efficiency of Plukenetia volubilis plants at two distinct growth stages as affected by irrigation and fertilization. Sci Rep. 2018;8:80.

28. Cardoso AÁ, de Magalhães Matos Obolari A, de Lima e Borges EE, da Silva $\mathrm{CJ}$, Rodrigues HS. Environmental factors on seed germination, seedling survival and initial growth of sacha inchi (Plukenetia volubilis L.). J Seed Sci. 2015;37(2):111-6.

29. Soimee W, Nakyai W, Charoensit P, Grandmottet F, Worasakwutiphong S, Phimnuan $\mathrm{P}$, et al. Evaluation of moisturizing and irritation potential of sacha inchi Oil. J Cosmet Dermatol. 2019;00:1-10.

30. Liu O, XuYK, Zhang P Na Z Tang T, ShiYX Chemical composition and oxidative evolution of Sacha Inchi (Plukentia volubilis L.) oil from Xishuangbanna (China). Grasas Aceites. 2014;65(1):e012.
31. Apak1 R, Gorinstein S, Böhm V, Schaich KM, Özyürek M, Güçlü K. Methods of measurement and evaluation of natural antioxidant capacity/activity (IUPAC Technical Report). Pure Appl. Chem. 2013;85(5):957-98.

32. Kodahl N, García-Dávila CR, Cachique D, Sørensen M, Lütken H. An in vitro seed germination protocol for Plukenetia volubilis L. Acta Hortic. 2018;1201.

33. Htike SL, Win SS, Thet WN. Investigation of phytochemicals, antioxidants and antimicrobial activities in sacha inchi (Plukenetia volubilis) press cake of Myanmar origin. Proceedings of the 1st International Conference on Innovations in Food Ingredients \& Food Safety (IFIFS 2018). 12-13 September 2018, Bangkok, Thailand.

34. Sembiring EN, Elya B, Sauriasari R. Phytochemical screening, total flavonoid and total phenolic content, and antioxidant activity of different parts of Caesalpinia bonduc (L.) Roxb. Pharmacog J. 2018;10(1):123-7.

35. Luo YL, Su ZL, Bi TJ, Cui XL, Lan QY. Salicylic acid improves chilling tolerance by affecting antioxidant enzymes and osmoregulators in sacha inchi (Plukenetia volubilis). Braz. J. Bot. 2014:37(3);357-63.

36. Nascimento AKL, Melo-Silveira RF Dantas-Santos N Fernandes JM Zucolotto SM, Rocha HAO, et al. Antioxidant and antiproliferative activities of leaf extracts from Plukenetia volubilis Linneo (Euphorbiaceae). Evid Based ComplementaryAltern Med. 2013.

37. Srichamnong W, Ting P, Pitchakarn P, Nuchuchua O, Temviriyanukul P. Safety assessment of Plukenetia volubilis (Inca peanut) seeds, leaves, and their products. Food Sci Nutr. 2018;1-8.

38. Bueno-Borges LB, Aurélio Sartim M, Carreño Gil C, Sampaio SV, Rodrigues $\mathrm{PHV}$, Regitano-d'Arce MAB. Sacha inchi seeds from sub-tropical cultivation: effects of roasting on antinutrients, antioxidant capacity and oxidative stability J Food Sci Technol. 2018

39. Chirinos R, Necochea O, Pedreschi R, Campos D. Sacha inchi (Plukenetia volubilis L.) shell: an alternative source of phenolic compounds and antioxidants. Int J Food Sci Tech. 2016:51:986-93.

40. Cachique DH, Solsol HR, Marco García SA, Arévalo Lo'pez LA, Kodahl N Vegetative propagation of the underutilized oilseed crop sacha inchi (Plukenetia volubilis L.). Genet Resour Crop Evol. 


\section{GRAPHICAL ABSTRACT}

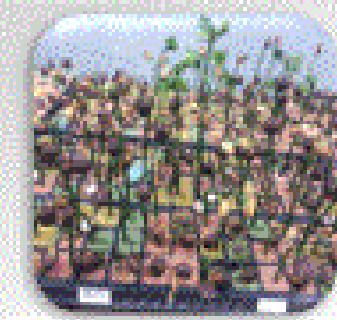

\section{Inca peanut} seedling
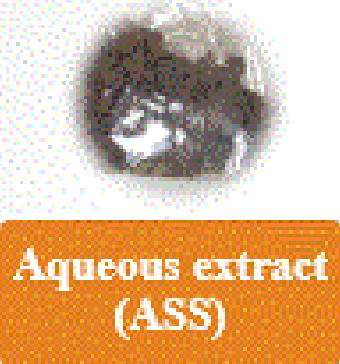
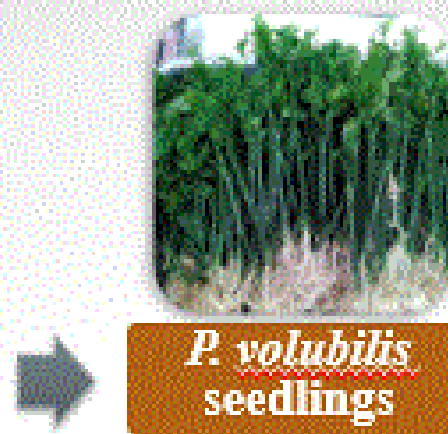

P. 10 Lubis seedilings

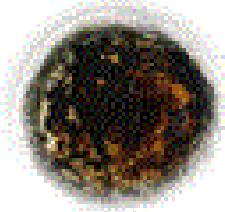

Fydro ethanelic extracts (HESS)

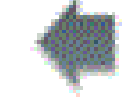

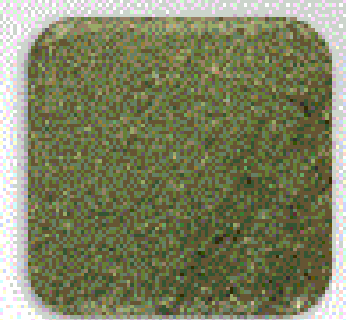

powder

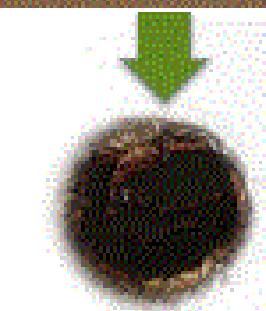

Ethanolic extracts (ESS)

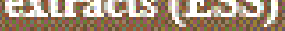

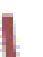
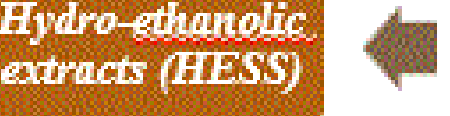

\footnotetext{
ESS were significantly highest amount on total phenolic compound and flavonoid contents. were showed more potent than all of the extracts

$>$ ESS has more potent on free radical scavenging higher than different solvents; DPPH, ABTS and FRAP.
}

\section{ABOUT AUTHORS}

- Darunee Puangpronpitag: Is a lecturer at the Faculty of Medicine, Mahasarakham University, Thailand, where she graduated in Bachelor of Sciences (Public Health), Master of sciences (Medical Biochemistry), and Doctor of Philosophy (Medical Biochemistry). Her research focused on the phytochemical content, antioxidant activity, and Molecular mechanism underlying anti-apoptotic \& anti-inflammatory effects of natural products. 
- Adisak Sumalee: Is a lecturer at the School of Health Science Sukhothai Thammathirat Open University, Thailand. He was graduated in Bachelor of Sciences (Applied Thai Traditional Medicine) and Master of Public Health. Now a day he is a Candidate Ph.D. Applied Thai Traditional Medicine at Thammasat University and his doctoral research focused on Effectiveness of Prasaprohyai extract capsule in allergic rhinitis patient comparing with Loratadine (Clinical trial phase III).

- Puangpaka Tankitjanon: Is a lecturer at the School of Health Science Sukhothai Thammathirat Open University, Thailand. She was graduated in Bachelor of Sciences (Applied Thai Traditional Medicine) and Master of Public Health in Health Education and Health Promotion. Ph.D. at Chulalongkorn University and her doctoral research focused on A Comparative Study of Court-Type Traditional Thai Massage versus Diclofenac Gel on Patients with Frozen Shoulder.

- Ampa Konsue: Is a lecturer at the Faculty of Medicine, Mahasarakham University, Thailand, where she graduated in Bachelor of Sciences (Applied Thai Traditional Medicine) and Master of sciences (Pharmaceutical chemistry and natural products). Her doctoral research focused on the evaluation of hypoglycemic effect and mechanisms of action and antioxidant activity of natural products.

Cite this article: Puangpronpitag D, Tankitjanon P, Sumalee A, Konsue A. Phytochemical Screening and Antioxidant Activities of the Seedling Extracts from Inca Peanut Plukenetia volubilis. Pharmacog J. 2021;13(1): 52-8. 